\title{
The role of colostral immunity in the effectiveness of serological detection of BLV
}

\author{
M.V. Petropavlovskiy", A.V. Lysov, N.A. Bezborodova \\ Federal State Budgetary Scientific Institution «Ural Federal Agrarian Scientific Research Centre, Ural \\ Branch of Russian Academy of Sciences», 620142 Yekaterinburg, Russia
}

\begin{abstract}
The purpose of our research was to study the influence of newborn calves colostral antibodies on the efficiency of bovine leukemia virus detection by serological methods. The research was conducted on the basis of agricultural organizations within the territory of the Ural Federal District (Chelyabinsk region). We undertook comprehensive diagnostic studies of calves fed with milk from seropositive and seronegative animals using polymerase chain reaction, ELISA test, and immunodiffusion test. Experimentally it was found that feeding calves with milk from seropositive and seronegative cows led to colostral immunoglobulins persistence for up to 3-3.5 months, in most of the animals, which may be associated with the end of suckling period in calves. At the same time, serological screening of animals during this period is difficult due to the influence of a high concentration of colostral antibodies. The obtained results of laboratory studies indicate the efficiency of PCR diagnostics in detecting a specific locus of the calf leukemia virus in animals at the early stages of the infectious process. PCR diagnostics provides an opportunity to early evaluation of calves with a latent course of BLV, excluding the influence of colostral immunity, thereby reducing the recovery time of enterprises from the leukemia virus by $20 \%$.
\end{abstract}

\section{Introduction}

The leukemia virus (BLV), an oncogenic member of the genus Deltaretrovirus, which causes contagious lymphoproliferative disease in cattle (EBL), has become a huge problem for animal husbandry in many countries of the world, including the Russian Federation [1]. In addition to the fact that the disease is widespread and causes multibillion annual economic damage to the industry, there is a possibility of public health threat [2 - 6].

The leukemia virus is an urgent problem for animal husbandry in the Ural region. The difficult epizootic situation persists in the Chelyabinsk and Kurgan regions, and in some unfavorable points in the Tyumen region has not been completely eliminated. The Sverdlovsk region is considered to be completely cured of BLV, the average infection rate of the entire cattle population of the region over the past 4 years has been $0.042 \%$.

The effectiveness of health-improving and preventive programs for bovine leukemia largely depends on the completeness and quality of diagnostic measures [7]. Currently, the

\footnotetext{
${ }^{*}$ Corresponding author: petropavlovsky_m@mail.ru
} 
main methods of serological detection of animals infected with the leukemia virus are based on the agar gel immunodiffusion (AGID) and enzyme-linked immunosorbent assay (ELISA) [8]. In addition, in recent years, the method of molecular genetic PCR analysis (polymerase chain reaction) has been increasingly used for these purposes, the high specificity of which is achieved due to the targeted detection of a fragment of proviral DNA. This method allows detecting single fragments of viral nucleic acids [9].

It was established that the spread of the leukemia virus among the cattle population occurs along the main horizontal (postnatal) and vertical (prenatal) transmission routes. Previously, it was noted that with the vertical path of transmission of the causative agent of leukemia from an infected animal, in case of all veterinary and sanitary standards and requirements were compliant, the development of the infectious process was observed in $5-8 \%$ of newborns [10 - 13]. It was found that the serological examination of newborn calves for the presence of antibodies to BLV may result in a false positive result, which may be due to the high concentration of $\mathrm{IgG}$ in colostrum from infected animals, which is used for calf feeding in the first months of life.

The purpose of the study: to evaluate the influence of colostral antibodies in newborn calves on the efficiency of bovine leukemia virus detection by serological methods.

\section{Materials and methods}

The research was carried out in the Ural SRVI - a structural division of the FSBSI UrFASRC Ural Branch of the Russian Academy of Sciences within the framework of State assignment of the Ministry of Education and Science of Russia in direction of the $160^{\text {th }}$ Program of the FSR State Academies of Sciences. Clinical research was conducted in agricultural organizations within the territory of the Ural Federal District (Chelyabinsk region).

Retrospective analysis and online analytical processing on the results of laboratory diagnostics of the leukemia virus were carried out on the basis of the materials extracted from veterinary reports of the executive authorities in the field of veterinary medicine of the subjects of the Russian Federation.

The objective of our research was Ural Black Pied cattle belonging to agricultural enterprises of the Ural Federal District. The subject of the study was blood samples, blood serum.

Blood samples for PCR studies were collected from animals into vacuum tubes with EDTA Venosafe - Hematology VF-0539DK (manufacturer TERUMO, Belgium).

Sample test in ELISA was performed using the VERI-test kit (manufacturer SPA "Narvak", Moscow) for detection of antibodies to bovine leukemia virus, in accordance with the instructions, as well as the SERELISA ${ }^{\circledR}$ BLV Ab Mono Blocking kit from Synbiotics company, France. The diagnostic kit - produced by the Kursk, "BIOK" - was used to perform immunodiffusion reaction.

Commercial test kit "GenPak DNA PCR test for Bovine leukemia virus DNA amplification" of IsoGen LLC (Moscow) was used for the diagnosis of bovine leukemia virus DNA samples. Real-time PCR was conducted on a Rotor-Gene 3000 amplifier (Australia).

Statistical digital data processing was carried out via standard Microsoft Office programs on a personal computer. The Mann-Whitney test was used for statistical comparison of the samples. The differences were considered statistically significant at $P<0.05$. The data were expressed as a percentage of control values to demonstrate an effect size. 


\section{Results}

We conducted monthly screening laboratory diagnostic studies of isolated after birth (from 20 days to 1 month) calves $(n=15)$ from seropositive cows. Newborn animals were fed with colostrum within the first 4 days of life and then with milk from seronegative cows. Laboratory tests for the detection of antibodies to BLV were carried out by serological tests (ELISA, AGID), and causative agent DNA was determined by PCR methods on a monthly basis within four months. The results of research are presented in Table 1.

Table 1. Results of monthly screening laboratory diagnostic tests for leukemia of calves obtained from seropositive cows, with milk feeding from seronegative animals, $n=15$.

\begin{tabular}{|l|c|c|c|c|c|c|c|c|c|c|}
\hline \multicolumn{2}{|l}{ Calves (n=15) } & \multicolumn{3}{|c|}{ I study } & \multicolumn{3}{c|}{ II study } & \multicolumn{3}{c|}{ III study } \\
\hline No. & Age & AGID & ELISA & PCR & AGID & ELISA & PCR & AGID & ELISA & PCR \\
\hline 5 & 20 days & - & - & - & - & - & + & + & + & + \\
\hline 6 & 1 month & + & + & + & - & - & + & + & + & + \\
\hline 11 & 20 days & - & - & - & - & - & + & + & + & - \\
\hline 12 & 20 days & - & - & - & - & - & + & + & + & + \\
\hline 14 & 1 month & + & $+/-$ & - & - & - & - & - & - & - \\
\hline
\end{tabular}

* group of calves №1-4,7,8,9,10,13,15 demonstrated negative test results for all diagnostic tests performed.

Thus, based on the presented tabular data, established during the first diagnostic study of a group of calves consisting of 15 animals, 2 animals (No. 6, No. 14) showed positive reaction to serological tests (AGID, ELISA). In one animal (No. 6) a specific section of the BLV DNA genome was detected by PCR. The remaining 13 tested newborn calves had negative results on all diagnostic methods of laboratory tests. Therefore, the prenatal BLV transmission mechanism was confirmed by PCR in $6.7 \%$ of calves born from seropositive cows. Based on this, the presence of antibodies to the leukemia virus in $13.3 \%$ of the test animals in the first study indicated a virus carriage in $6.7 \%$ (No. 6), and a possible detection of transplacental antibodies in the blood serum in $6.7 \%$ (No. 14).

In a second study, a month later, a positive result for leukemia by PCR was confirmed in calf No. 6, and expansion in the number of infected animals by $20 \%$ (up to $26.6 \%$ ) was also found. The DNA BLV fragment was detected in animals No.5, 11, and 12.

At the same time, transplacental and proprietary antiviral immunoglobulins (in infected animals) were not detected in any animal by ELISA test. This indicated the elimination of transplacental (maternal) immunoglobulins during this period and the early formation of a specific protective humoral immune response in susceptible animals.

During the third comprehensive diagnostic study, conducted a month later, the result of the previous screening was also confirmed. Immunoglobulins were found in all infected animals.

In addition, the reliability of the research was confirmed by a biopsy on experimental lambs, the fragment of the BLV genome in which was also determined by PCR.

It should be noted that the increase in the number of infected animals by $20 \%$ in the study group by the 3rd month of laboratory diagnostic studies indicates the high importance of methods for early diagnostics of infected animals and the necessity of forehanded segregation of identified virus carriers in a separate herd during health-improving anti-epizootic measures.

The next stage of the experiment was to conduct complex laboratory and diagnostic studies of a group of calves $(n=15)$ isolated after birth (from 20 days to 4 months) from seropositive cows, the newborn animals were fed with combined pasteurized milk from 
seropositive cows. The research was conducted to determine the influence of colostral immunity on the efficiency of serological detection of BLV. The results of complex laboratory and diagnostic studies of this group of animals are presented in Table 2.

Table 2. Results of complex screening laboratory diagnostic tests for leukemia of calves obtained from seropositive cows, with milk feeding from seropositive animals, $\mathrm{n}=15$.

\begin{tabular}{|c|c|c|c|c|c|c|c|c|c|c|c|c|c|c|}
\hline \multirow{2}{*}{\multicolumn{2}{|c|}{ Calves, n=15 }} & \multicolumn{5}{|c|}{ Stage I of research } & \multicolumn{5}{|c|}{ Stage II of research } & \multirow{2}{*}{\multicolumn{3}{|c|}{$\frac{\text { Stage III of research }}{\text { September }}$}} \\
\hline & & \multicolumn{2}{|c|}{ March } & \multicolumn{2}{|c|}{ May } & & \multicolumn{2}{|c|}{ June } & \multicolumn{3}{|c|}{ July } & & & \\
\hline No. & $\begin{array}{l}\text { age } \\
\text { age }\end{array}$ & $\begin{array}{c}\text { AGI } \\
\text { D }\end{array}$ & ELISA & $\begin{array}{c}\text { AGI } \\
\text { D }\end{array}$ & ELISA & PCR & $\begin{array}{c}\text { AGI } \\
\text { D }\end{array}$ & ELISA & $\begin{array}{c}\text { AGI } \\
\text { D }\end{array}$ & ELISA & PCR & $\begin{array}{c}\text { AGI } \\
\text { D }\end{array}$ & ELISA & $\begin{array}{c}\mathbf{P C} \\
\mathbf{R}\end{array}$ \\
\hline 1 & $\begin{array}{c}1,5 \\
\text { month }\end{array}$ & - & + & - & - & - & - & - & - & - & - & - & - & - \\
\hline 2 & $\begin{array}{c}4 \\
\text { month }\end{array}$ & $+/-$ & + & + & + & + & + & + & + & + & + & - & - & - \\
\hline 3 & $\begin{array}{c}3 \\
\text { month }\end{array}$ & + & + & + & + & + & + & + & - & - & + & + & + & + \\
\hline 4 & $\begin{array}{c}3 \\
\text { month }\end{array}$ & $+/-$ & + & - & - & $\mathrm{n} / \mathrm{a}$ & - & + & - & - & - & - & - & - \\
\hline 5 & $\begin{array}{c}3 \\
\text { month }\end{array}$ & + & + & - & + & $\mathrm{n} / \mathrm{a}$ & - & - & - & - & - & - & - & - \\
\hline 6 & 25 days & & & + & + & + & + & + & + & + & - & $+/-$ & + & - \\
\hline 7 & 20 days & & & + & + & $n / a$ & + & + & - & + & - & - & - & - \\
\hline 8 & 20 days & & & + & + & $\mathrm{n} / \mathrm{a}$ & + & + & + & + & - & - & - & - \\
\hline 9 & $\begin{array}{c}1 \\
\text { month }\end{array}$ & & & + & + & + & + & + & + & + & + & + & + & + \\
\hline 10 & $\begin{array}{c}1 \\
\text { month }\end{array}$ & & & + & + & - & - & - & + & + & - & - & - & - \\
\hline 11 & $\begin{array}{c}1,5 \\
\text { month }\end{array}$ & & & + & + & - & - & - & + & + & + & - & - & - \\
\hline 12 & $\begin{array}{c}1,5 \\
\text { month }\end{array}$ & & & - & + & - & - & - & - & - & - & - & - & - \\
\hline 13 & 20 days & & & & & & & & + & + & - & $+/-$ & + & - \\
\hline 14 & 25 days & & & & & & & & + & + & - & + & + & - \\
\hline 15 & 20 days & & & & & & & & + & + & - & + & + & - \\
\hline
\end{tabular}

Thus, serological screening of calves (milk feeding from AGID +/-) from seropositive cows established that colostral and transplacental immunoglobulins were detected in all animals during the first comprehensive serological study. The use of molecular genetic methods (PCR) and the bioasssay method made it possible to identify infected animals in the first month and conduct a reference control. Thus, out of the 12 animals in the first PCR test at the second stage, the BLV DNA locus was detected in 4 calves (No. 2, 3, 6, 9), at the second stage of studies and subsequent ones - additionally in one animal (No. 11), which could indicate spreading of infection due to stocking density. No DNA BLV fragments were detected by PCR in the remaining animals, but positive results of serological studies indicated the presence of specific colostral immunoglobulins. The use of PCR with subsequent bioassay suggested that colostral immunoglobulins persist until the end of the suckling period in calf and eliminated after the transition of animals to a standard diet, so their presence in most calves from the study group was noted in the first and second months of life. Thus, it was found that colostral immunity was preserved from 2.5 to 3.5 months in the majority of the studied animals.

At the same time, single false-negative PCR results in the calves studied (No. 6, No. 4) could indicate insufficient specificity and sensitivity of the commercial test kit for PCR reaction. 
To confirm this assumption, blood samples had been taken from these animals, a leukoconcentrate was prepared, and a bioassay was performed on laboratory animals (small cattle). As a result of the leukemic process reproduction in experimental laboratory animals, positive serological and molecular genetic results were obtained.

\section{Conclusion and discussion}

The data obtained during the experiment indicate the efficiency of molecular genetic methods for detecting infected animals in the early stages of the viral leukemia process. Serological screening of calves under 6 months of age at recovery facilities is difficult, due to the influence of high concentrations of maternal transplacental or colostral antibodies, which mask the presence of antiviral immunoglobulins in calves. The detection of false-negative serological results could be associated with the development of immunological tolerance. Immunological tolerance is the organism's immune system inability to respond to a specific antigen. The time of its formation varies from several hours to several days, and its duration depends on the persistence of the antigen in the organism and the rate of formation of immunocompetent cells from their precursors. Induction of tolerance is promoted by nonspecific immunosuppression (including under the influence of drugs). Experimentally it was found that feeding calves with milk from seropositive and seronegative cows led to colostral immunoglobulins persistence for up to 3-3.5 months, in most of the animals, which may be associated with the end of suckling period in calves. Elimination of colostral immunoglobulins is caused by the transition of animals to a standard diet.

The use of polymerase chain reaction increased chances for early detection of calves with a latent course of BLV, excluding the influence of colostral immunity, thereby reducing the recovery time of enterprises from the leukemia virus by $20 \%$.

False-negative results of PCR tests in calves could indicate insufficient specificity and sensitivity of the commercial test kit for PCR reaction. This is possible with a low concentration of matrix DNA in the sample during the PCR reaction, which often indicates a low viral load in the tested calves. The occurrence of PCR false-positive results may be associated with insufficient complementarity of PCR primers at the planting sites, which indicates the need for additional study of the BLV genome variability.

\section{References}

1. OIE World Organization for Animal Health, Enzootic Bovine Leukosis. World Anim Heal Inf Database, Dis information, List Ctries by Sanit Situat. Available at: http://www.oie.int/wahis_2/public/wahid.php/Diseaseinformation/statuslist (2019)

2. A. Gao, V.L. Kouznetsova, I.F. Tsigelny, Microb Pathog, 149, 104417 (2020). doi: 10.1016/j.micpath.2020.104417. Epub 2020 Jul 27. PMID: 32731009; PMCID: PMC7384413.

3. G.C. Buehring, H.M. Shen, H.M. Jensen, K.Y. Choi, D. Sun, G. Nuovo, Emerg Infect Dis. 20(5), 772-82 (2014) doi: 10.3201/eid2005.131298. PMID: 24750974; PMCID: PMC4012802.

4. G.C. Buehring, A. DeLaney, H. Shen, D.L. Chu, N. Razavian, D.A. Schwartz, Z.R. Demkovich, M.N. Bates, BMC Infect Dis. 19(1), 297 (2019) doi: 10.1186/s12879-0193891-9. PMID: 30940091; PMCID: PMC6444872

5. G. Mesa, J.C. Ulloa, A.M. Uribe, M.F. Gutierrez, Open Journal of Medical Microbiology, 3, $\quad 84-90 \quad$ (2013) doi:10.4236/ojmm.2013.31013 http://www.scirp.org/journal/ojmm 
6. N.N. Olaya-Galán, A.P. Corredor-Figueroa, T.C. Guzmán-Garzón, K.S. RíosHernandez, S.P. Salas-Cárdenas, M.A. Patarroyo, M.F. Gutierrez, Epidemiol Infect, 145(15), 3125-3130 (2017) doi: 10.1017/S095026881700222

7. I.M. Donnik [and others.], Experimental data on the effectiveness of diagnostic studies in the early stages of the virus carrier virus of cattle leukemia virus, 26 (THEM. IRA UTK LLC, Yekaterinburg, 2011)

8. I.M. Donnik, G.A. Jailidi, S.V. Tikhonov, Veterinary of the Kuban, 5, 15-19 (2013)

9. J.P. Jaworski, A. Pluta, M. Rola-Łuszczak, S.L. McGowan, C. Finnegan, K. Heenemann, H.A. Carignano, I. Alvarez, K. Murakami, L. Willems, T.W. Vahlenkamp, K.G. Trono, B. Choudhury, J. Kuźmak, J Clin Microbiol., 56(7), e00304-18 (2018) doi: 10.1128/JCM.00304-18. PMID: 29669790; PMCID: PMC6018327

10. M.I. Gulyukin, O.V. Kapustina, I.Yu. Ezdakova, S.V. Valtsiferova, T.V. Stepanova, M. Anoyatbekov, Problems of Virology, Russian journal, 64(4), 173-177 (2019) URL :https://doi.org/10.36233/0507-4088-2019-64-4-173-177

11. A.F. Valikhov, Moloch.prom-st, 9, 74-77 (2018)

12. I.M. Donnik, I.A. Shkuratova, A.T. Tatarchuk [et al.], Regulatory issues in veterinary medicine 2, 42-46 (2015)

13. S. Kobayashi, T. Tsutsui, T. Yamamoto, Y. Hayama et al., Veterinary Research, 6, 1-9, $3(2010)$ 